\title{
The Extent of Correlation Between the Budgetary Process Elements of Budgetary Control and Budgetary Participation with Service Delivery in Institutions of Higher Learning in Kenya: The Case of Multimedia University of Kenya
}

\author{
Fairoozah Basward, Dr. Mary Mugo, and Dr. Gichuhi Kimani \\ Faculty of Business and Economics, Multimedia \\ University of Kenya \\ DOI: 10.29322/IJSRP.11.09.2021.p11708 \\ http://dx.doi.org/10.29322/IJSRP.11.09.2021.p11708
}

\begin{abstract}
The study was aimed at assessing the extent of correlation between the budgetary process elements of budgetary control and budgetary participation with quality service delivery in public universities in Kenya, focusing on a case study of Multimedia University of Kenya (MMU). A sample of 117 staff members of the institution provided the primary data utilized in the research. The first independent variable targeting of budgetary control was measured by performance indicators, budget analysis, and budget performance reports, while the second independent variable focusing on budgetary participation was measured using staff opinions, suggestions, request, follow ups, and proposals. The dependent variable of service delivery was captured in terms of timely debt payments, efficiency, meeting obligations, quality of service, and customer relations. Data collected were analysed using the Spearman correlation coefficient run on the SPSS application software. The findings of the research indicated a fairly strong positive and significant correlation coefficient of 0.692 between budgetary control elements and service delivery in Multimedia University, leading to the rejection of the null hypothesis: $\mathrm{H}_{0}$ : There is no association between budgetary control and service delivery at the Multimedia University. The association between budgetary participation and perceived service delivery at the university equally yielded a strong positive and significant correlation coefficient of 0.722 that lead to the rejection of the null hypothesis that stipulated absence of an association between the two variables. It was the conclusion of the research that, as echoed by other researchers, budgeting control and budgeting participation of stakeholders, budget analysis and feedback, constitute elements of the budgetary process that lead to provision of quality services by organizations and which management of service organizations, such as universities should not overlook in the budgeting process. It was the recommendation of the research that other elements of the budgeting process including budgetary training and/or experience should be accorded to other stakeholders in the institution and not just the budget managers as well as for better budget-oriented service delivery in the organization
\end{abstract}

Index Terms - Budget control, budgetary participation, service delivery, correlational analysis, institution of higher learning.

\section{INTRODUCTION}

According to the Cambridge English dictionary a Budget is 'a plan to show how much money a person or organisation will earn and how much they will need or be able to spend'. According to Esuku (2003), budget implementation is the actualization of a suggested strategy of expenditure on accessible resources within an institution with a goal of achieving objectives. Budgeting is very important to any firm or business. Without a budget a firm rarely achieves much. Strategic goals as set by most institutions depend on budgets for their achievement. This entails setting of the goals and performance evaluation as per the set goals.

The budgeting process in public institutions in Kenya has faced some challenges, where for instance, to complete some projects, more than four times the intended budget has been utilized. In other words, owing to poor implementation processes the returns are greatly affected. Budget adherence is one of the most effective and useful management accounting methods that, when correctly interpreted and applied, can provide improved results (Kamau, Rotich, \& Anyango, 2017). Institutions and business managers need efficient budgeting process for their institutions and businesses respectively to thrive. An appropriately implemented budget has the capability to promote socio economy development. . Without a good budgeting mechanism, this would be difficult to do (Adongo, 2013; Kibunja, 2017). Budgeting is one of the most effective and valuable management accounting methods that, when properly understood and applied, can produce substantial results (Suberu, 2010; Abdallah, 2018). According to (Adongo, 2013; Ogweche and Muturi, 2019), Kenya has implemented a range of budgetary reforms since independence, with the aim of maximizing the benefits accruable from public sector investment through budget reforms. In spite 
of the potential benefits accrued from budgeting, there is scepticism on budget performance of State Corporations in Kenya (Kamau, Rotich \& Anyango, 2017)

In Kenya, both public and private universities play a key role in facilitating higher education. Public universities are usually funded by the government whereby in most cases it is not substantial compared to the high expenditure of the universities activities. Higher learning institutions are being faced by countless challenges all over Africa and Kenya is no exemption. According to Kimathi and Henry (2014), there is no question that the increased demand for higher education would result in a crisis in Kenyan institutions of higher learning. The challenges facing public universities include; reduced financial support from the government, infrastructure amenities and decline in quality of services rendered. The situation facing Kenyan universities calls for implementation of more effective budgeting processes in for more effective utilization and management scare resources the face of decreased government funding and increased student enrolment.

Budgetary control, according to Adan (2012), is a proven management instrument that aids organization management and improves the performance of any economy in a variety of ways. Its primary function is to serve as a guide in financial planning operators; it also establishes limits for departmental excesses. It helps administrative officials to make careful analysis of all existing operations, thereby justifying expanding and eliminating or restricting excesses. Budgeting and control entails a distinct pattern of decisions in an organization which is capable of determining its objectives, purposes or goals, and how these goals are achieved by establishing principal policies and plans. However, the inability to recognize the problem concerned and fixing boundaries creates an obstacle for the successful implementation of budgeting and control. According to (Robinson, 2007; Scott and Enu-kwesi, 2018), increasing public involvement in the budgeting process increases the effectiveness of health, education, and other services. Kamau, Rotich, and Anyango (2017), argue that that budget participation had the greatest impact on budget efficiency.

This study is aimed at investigating how service delivery is affected by the budgeting process elements of budget control and budgetary participation in one of Kenya's public universities; Multimedia University of Kenya.

\section{RESEARCH ELABORATIONS}

\section{Review of Theoretical and Empirical Literature}

On the side of theoretical literature, this research was guided by two theories: The Agency Theory and the Theory of Control. The Agency theory, developed by Berle and Means (1932), discloses why conflicts exist between the managers and the shareholders or the owners of a company These conflicts lead to agency costs. The main aim of the Agency theory is to reduce information irregularity in order for the principal (shareholder) and the agent (managers) to be in the same page by use of sanctions and likelihood of incentives. The main goal of the Agency theory is to organize the contractual relationship amid the two groups in order for the agents to act in a manner that will maximize the interests of the principals. This theory has a bearing on this research in that the managers deciding on the budgeting process in the university, that is top management, can be deemed as the agent while the other stakeholders in the outcomes of the budgetary process such as other workers, students, and so on, are deemed as shareholders. On the other hand, the theory of control specifies the requirements of organizations in providing basic and social services to the citizens. It indicates that government owned industries is a basic principle of control on those scarce resources they are meant to manage (Robinson, 2009). This is due to the fact that if there is no sufficient control of resources in the institutions, it will be close to impossible to monitor budgets. Ample control is necessary for every institution, be it private or public worldwide.

A few empirical works have investigated the relationship between the budgetary process elements of control and budgetary participation with service delivery or organizational performance in Kenya and elsewhere. Kimani (2014) investigated the impact of budgetary control in non-governmental organizations on their effectiveness. According to the results of the study, budgetary regulation had a minimal impact on NGO success in Kenya. The research by Lerno (2016) who investigated the effect of internal control practices on county government efficiency in Kenya., with the conclusion was that, while Kenyan county governments have implemented internal control procedures, these procedures have not resulted in a significant increase in county government efficiency. Another Kenyan-based research by by Rutto and Oluoch (2017) had the specific objectives determining the effect of human capital budgetary control cash flow budgetary control on financial performance of savings and credit cooperative organizations Findings showed that human capital budgetary control and cash flow budgetary control had significant effect on financial performance of savings and credit Cooperative organization. The research recommended the need for communication of details of human capital budget policy and guidelines to the individuals tasked with the preparation of the budget. As early as 2009, Alau, Salam and Abdikadir, had concluded that, through seminars and conferences, stakeholders' understanding of budget execution could be improved, when they investigated the impact of the budgeting process on budget efficiency in the public sector in Nigeria's Kwara province

Kamau, Rotich, and Anyango (2017), in their research aimed at determining how the budgeting process influenced the budget performance of state corporations in Kenya, with a particular emphasis on Kenyatta National Hospital; found that that budget participation had the greatest impact on budget efficiency. Gonçalves (2014), while empirically investigating whether participatory budgeting was used in Brazilian municipalities determined that implementing participatory budgeting is associated 
with increased spending on basic hygiene and health facilities, resulting in improved water and sanitation connections, waste disposal, and a significant reduction in child mortality rates. Rotich K.C (2015) had also determined the budgetary participation was crucial to a budget implementation that resulted in meeting objectives more effectively, when he investigated factors affecting budget utilization Kericho County, Kenya.

\section{Statement of the Problem}

The demand for higher education in Kenya has grown by leaps and bounds within the last few decades, and with it has grown the need for increased funding in the context of huge budgets for these institutions of higher learning. Although both public and private universities currently face huge budgets due to the growth of enrolment in student numbers and the need to provide supporting facilities, the public universities with an average of over 15000 students bare the brand of ballooning budgets more. This has led to management of these universities calling for increased funding from a Government that is seemingly cashstrapped, and proposing the hiking of tuition fee for students. Part solution to the financial problems bedevilling the university may also lie in the proper planning and implementation of their budgets. For the public universities, in order to provide quality service from an increasingly shrinking budget in the face of a growing number of students, the problems call for stringent planning and implementation of the budgetary process that incorporates the elements of budgetary control, budgetary participation by all stakeholders, proper budgetary feedback, and budgetary experience such as training. This research investigated the relationship between two budgetary process elements of budgetary control and budgetary participation with service delivery at a public university in Kenya; The Multimedia University of Kenya.

\section{Objectives of the Research}

The overall objective of the study was to assess the extent of budgetary process elements of budgetary control and budgetary participation with perceived service delivery of the state-owned Multimedia University in Kenya. The research therefore had two specific objectives stated as:

1. Assess the effect of budgetary control on service delivery in public universities; a case of Multimedia University of Kenya.

2. Establish the effect of budgetary participation on service delivery in public universities; a case of Multimedia University of Kenya.

The specific objectives were investigated (tested) using two hypotheses stated as:

1. $\mathrm{H}_{01}$ : Budgetary control has no significant effect on service delivery in public universities in Kenya.

2. $\mathrm{H}_{02}$ : Budgetary participation has no significant effect on service delivery in public universities in Kenya.

The study variables are portrayed in the conceptual framework below.

Figure 1: The conceptual framework

Independent Variables

\section{Budgetary Control}

- Performance indicators

- Budget analysis

- Budget evaluation reports

\section{Budgetary Participation}

- Opinions

- Suggestions

- Requests

- Follow ups

- Proposals

\section{Dependent Variable}

\section{Service Deliver}

- Timely debt payments

- Efficiency

- Meeting obligations

- Quality services

- Customer relations 
In the first specific objective, the research aimed to analyse the: performance indicators; budget analysis; and budget evaluation reports with the perceived service delivery measured in terms of timely debt payments, efficiency, meeting of obligations, delivery of quality service, and customer relations. In the second specific objective it aimed to analyse the budgetary participation components of staff opinions, suggestions, request, follow ups, and proposals with perceived service delivery

\section{Research Methodology}

The study utilized primary data collected by a semi-structured questionnaire compressing of five-point Likert scale from the 117 responding sample from a sample size of 179 comprising of 24 managers (Deans of schools, Heads of departments, and Heads of General University administrative service departments of Finance, Huma Resource, Registry, Information Technology, Library, and Medical) and 155 other staff comprised of lecturers and various support staff in the departments of the university. To measure the extent of association between the independent and dependent variables of study the inferential statistical tool comprising of Spearman rank correlation coefficient, together with appropriate hypothesis statements for the specific research objectives was employed. The Spearman correlation coefficient was appropriate for this study in investigating the relationship between the independent and dependent variables; perceived use of thee budgetary control process and effectiveness of service delivery, because, unlike the Pearson correlation coefficient, it does not assume that the data is interval or ratio variables (i.e direct continuous numerical measurements). Huizingh ((2007) points out that if such assumptions are not met, and the data for analysis is in the form of ordinal variables (such as Likert-scale values) then the non-parametric tests of the Spearman correlation coefficient or the Kendall's tau, form good alternatives.

\section{DATA ANALYSIS AND INTERPRETATION}

\section{Test for Questionnaire Adequacy - Cronbach's Reliability Test}

To test for the reliability of the questionnaire used in the research, Cronbach's reliability test was employed using SPSS software application. The results is indicated in Table 1 below

Table 1: Reliability Statistics

Reliability Statistics

\begin{tabular}{|r|r|}
\hline $\begin{array}{c}\text { Cronbach's } \\
\text { Alpha }\end{array}$ & N of Items \\
\hline .920 & 5 \\
\hline
\end{tabular}

A Cronbach's alpha $(\alpha)$ of 0.920 (measure of scalability) implies that the questionnaire used in the research was reliable. A value of 0.7 to 0.8 is an acceptable value for Cronbach's $\alpha$ (Field, 2009). Values substantially lower indicate an unacceptable scale.

\section{Test for Correlation Between the Independent and Dependent Variables}

The null hypotheses for the research was formulated as;

1. $\mathrm{H}_{01}$ : Budgetary control has no significant effect on service delivery in public universities in Kenya at the Multimedia University of Kenya.

2. $\mathrm{H}_{02}$ : Budgetary participation has no significant effect on service delivery in public universities in Kenya at the Multimedia University of Kenya.

To determine the extent of correlation between the independent and dependent variables of study, and test the above hypotheses, the data of the paired Likert-Scale ranking of the 179 responded (an average ranking score was computed for each respondent) of the independent variables (budgetary control and budgetary participation) and the dependent variable (service delivery) were entered into and processed with the SPSS software application.

Table 1: The Spearman's rho correlation between budgetary control and service delivery

Correlations

\begin{tabular}{|c|c|c|c|c|}
\hline & & & $\begin{array}{l}\text { Budgetary } \\
\text { Control }\end{array}$ & $\begin{array}{l}\text { Service } \\
\text { Delivery }\end{array}$ \\
\hline \multirow[t]{4}{*}{ Spearman's rho } & Budgetary Control & Correlation Coefficient & 1.000 & $.692^{* *}$ \\
\hline & & Sig. (2-tailed) & & .000 \\
\hline & & $\mathrm{N}$ & 117 & 117 \\
\hline & Service Delivery & Correlation Coefficient & $.692^{* * *}$ & 1.000 \\
\hline
\end{tabular}




\begin{tabular}{|l|r|r|}
\hline Sig. (2-tailed) & .000 & 117 \\
$\mathrm{~N}$ & 117 \\
\hline
\end{tabular}

**. Correlation is significant at the 0.01 level (2-tailed).

The correlation coefficient of 0.692 indicates a fairly strong positive association between budgetary controls as perceived by the 117 respondents in the sample of study. The p-value of 0.000 falls below critical value or threshold value of 0.05 and leads to the rejection of the null hypothesis, as it implies that the probability that the relationship (association) found is a matter of is considerably low. The conclusion is that the staffs of the university perceive the process of budgetary control and service delivery to be positively associated.

Table 2: The Spearman's rho correlation between budgetary participation and service delivery

\begin{tabular}{|c|c|c|c|c|}
\hline \multicolumn{5}{|c|}{ Correlations } \\
\hline & & & $\begin{array}{c}\text { Budgeting } \\
\text { Participation }\end{array}$ & $\begin{array}{l}\text { Service } \\
\text { Delivery }\end{array}$ \\
\hline \multirow[t]{6}{*}{ Spearman's rho } & \multirow[t]{3}{*}{ Budgeting Participation } & Correlation Coefficient & 1.000 & $.722^{* *}$ \\
\hline & & Sig. (2-tailed) & & .000 \\
\hline & & $\mathrm{N}$ & 117 & 117 \\
\hline & \multirow[t]{3}{*}{ Service Delivery } & Correlation Coefficient & $.722^{* *}$ & 1.000 \\
\hline & & Sig. (2-tailed) & .000 & \\
\hline & & $\mathrm{N}$ & 117 & 117 \\
\hline
\end{tabular}

**. Correlation is significant at the 0.01 level (2-tailed).

The correlation coefficient of 0.722 indicates a strong positive association between budgetary participation as perceived by the 117 respondents in the sample of study. The p-value of 0.000 leads to the rejection of the null hypothesis. The conclusion is that the staff of the university perceive the process of budgetary participation and service delivery to be positively associated.

\section{DISCUSSION AND CONCLUSIONS}

From the output of the Spearman correlation analysis, using ranked or ordinal data for paired 117 respondents in the sample on the pair of each of the independent variables (budgetary control and budgetary participation) and the dependent variable (service delivery), both budgetary control and budgetary participation were, in general, perceived have a positive and significant relationship with quality of service delivery. This findings concur with those of others in literature, for instance, Lerno (2016), Rutto and Oluoch (2017), and Rotich (2015). Although the findings of this research support the principle of the advantages accruing to an effective budgetary implementation process, public universities in Kenya, including the Multimedia University, are largely funded by the Government, with the result that the budgeting process may be carried out by top management of the universities, and who are therefore answerable or liaise with The Treasury, at the exclusion of other stakeholders (other university staff, students, parents, to mention but some), during budget creation and implementation. It is therefore not strange to read of or hear from local media, misuse of funds by some of the public universities' top management. Although such allegations require thorough investigation to authenticate them, as the adage goes, "where there is smoke, there is fire", and they are probably a pointer to non-stringent budget implementation policies and unaccountability in this process. All in all, if the tenets of good budgetary implementation process involving stakeholder participation, budgetary control, feedback and transparency , and budgetary experience, are adhered to, universities will benefit more from effective service delivery accruing to budget-oriented planning. 


\section{REFERENCES}

Abdallah, S. (2018). Effect of budgeting process on financial performance of County Government of Kwale in Kenya.

Unpublished MBA Project. School of Business. University of Nairobi. Nairobi.

Adan, H. (2012). Influence of stakeholders role on performance of constituencies 'Development Fund Projects. Unpublished PPM Project, University of Nairobi.

Alau, S. A. (2009). An Assessment of the Influence of Budget Process on Budget Performance:

A case study of Kwara State, Nigeria.

Adongo, K. O. (2013). Budgetary control as a measure of financial performance of state corporations in

Kenya. International Journal of Accounting and Taxation, 1 (1), 23- 62.

Berle, A., \& Means, G. (1932). The modern corporate and private property. McMillian, New York, NY.

Esuku, K. (2003). Bugetary controls and perceived financial performance of tertiary institutions under (btvet).

Faculty of Economics and Graduate program in Mnagaement, Indonesian Catholic University Atma.

Field, A. (2009). Discovering statistics using SPSS. London: Sage Publications Ltd.

Gonçalves, S. (2014). The effects of participatory budgeting on municipal expenditures and infant mortality in

Brazil. World Development, 53, 94-110.

Huizingh, E. (2007). Applied statistics with SPSS: Sage.

Kamau, J., Rotich, G., \& Anyango, W. (2017). Effect of budgeting process on budget performance of state corporations in Kenya:

A case of Kenyatta National Hospital. International Academic Journal of Human Resource and Business Administration, 2(3),

$255-281$.

Kimani, R. N. (2014). The effect of budgetary control on effectiveness of nongovernmental organisations in

Kenya. Unpublished PhD Thesis. School of Business University of Nairobi. Nairobi.

Kimathi, K. J., \& Henry, E. E. (2014). An Evaluation of Quality of University Education in $\quad$ Kenya during this Massification Era. Mediterranean Journal of Social Sciences, $\quad 5(5), \quad 345$.

Lerno, D. L. (2016). Relationship between Internal Controls and Performance of County Government in Kenya. Unpublished MBA Project. School of Business. University of Nairobi. Nairobi.

Ogweche, J. \& Muturi, W. (2019). Factors Influencing Adherence to Budgets in Nyamira County Hospitals, Kenya. IJARKE Business \& Management Journal DOI: 10.32898/ibmj.01/1.4article12.

Robinson, M. (2007). Does decentralisation improve equity and efficiency in public service delivery provision? IDS Bulletin, $38(1), 7-17$.

Robinson, M., \& Last, D. (2009). Budgetary Control Model: The Process of Translation. Accounting, Organization and Society, 16(5/6), 547-570.

Rotich K.C (2015). Factors affecting budget utilization Kericho County. International

Journal of Economics, Commerce and

Management United Kingdom, 3 (6) 
Rutto, K. J. \& Oluoch , O. (2017). Effect of budgetary control on financial performance of savings and credit cooperative organizations in Nairobi County. The Strategic Journal of Business and Change Management, 4 (2), 797 - 816

Scott, G. \& Enu- Kwesi, F.(2018). Role of Budgeting Practices in Service Delivery in the Public Sector: A Study of District Assemblies in Ghana. Human Resource Management Research 2018, 8(2): 23-33.

Suberu, S. B. (2010). Budgeting strategies in selected federal polytechnic libraries in Nigeria.

Samaru Journal of Information Studies Vol. 10.

\section{AUTHORS}

First Author: Fairoozah Basward is a post graduate student at the faculty of Business and Economics, at Multimedia University of Kenya. fairoozah@gmail.com

Second Author: Dr. Mary Mugo, PhD, is a senior lecturer and Dean Faculty of Business and Economics at Multimedia University of Kenya. mugojemima@gmail.com

Third Author: Dr. Gichuhi Kimani, PhD, is a senior lecturer School of Business, at Africa Nazarene University. kgichuhi@anu.ac.ke 